\title{
A household waste stream analysis in a rural Mexican location
}

\section{Luis VELAZQUEZ, Carlos ANAYA, Omar CONTRERAS-AgANZA, Nora MUNGUIA}

University of Sonora, Mexico

\begin{abstract}
:
Aim: This paper presents a waste stream analysis with the purpose of identifying opportunities to reduce environmental and health risks within a small rural population in Northwestern Mexico by following the Environmental Protection Agency's waste management hierarchy.

Design / Research methods: The study consisted of three phases. Firstly, a one-stage cluster sampling was conducted to characterize the household waste in this rural population. A cluster in this study was a block. There were 54 clusters, but only 40 with occupied houses. The clusters were selected by simple random sampling. During the second phase of this study, a survey was conducted to examine the waste management practices of the residents of sampled houses. Considering that 51 were the inhabited houses in the sampled clusters, a simple random sampling for finite populations was selected. Finally, a quadrant sampling method was conducted to characterize the waste material in a municipal landfill. The total area of the municipal landfill site was divided into black and white quadrants. The white color represented tails and the black color represented heads. The color of the sampled quadrants was selected after 50 virtual coin flips for true randomness.
\end{abstract}

Conclusions/findings: The findings from this study indicate a willingness of the inhabitants in this rural location to participate in source reduction initiatives. The findings also showed that organic waste was the predominant material in household waste composition. Therefore, there are opportunities to enhance composting at home or even implement a community composting program.

Contact details: Luis VELAZQUES. University of Sonora, Luis Encinas y Rosales S/N. Building 5M CP 83,000 Hermosillo, Sonora Mexico/ E-mail: luis.velazquez@unison.mx (Luis VELAZQUEZ), canaya@industrial.uson.mx (Carlos ANAYA), omarc92@gmail.com (Omar CONTRERAS-AGANZA, nora.munguia@unison.mx (Nora MUNGUIA).

Received: 14.04.2020, Revised: 11.06.2020, Revised: 20.08.2020, Accepted: 20.08.2020

doi: http://dx.doi.org/10.29015/cerem.875 
Originality/value of the article: Based on the waste stream analysis, there are opportunities to reduce the environmental and health risks at a small rural zone in Northwestern Mexico. In this regard, this study can serve as an example to analyze and compare sustainable opportunities in other rural zones around the world.

Keywords: Waste management, Rural Development, Landfill, Waste Stream Analysis.

JEL: Q510, Q530, R110

\section{Introduction}

The management of municipal solid waste is complex because it involves multiple environmental and socio-economic criteria (Soltani et al. 2015). Recognizing this complexity, the United States Environmental Protection Agency (EPA 2017) created the Waste Management inverted pyramid to help guide "greener" waste-management practices. In particular, it gives more priority to prevention over control practices.

An integrated household management program is an example of good practice that encompasses preventing, reducing, and eliminating environmental risks along the waste stream from the waste that is generated to its final disposal (Munguia et al. 2010). Similarly, alternatives to decrease the generation of waste at the source are considered as an essential element to "greener" waste management practices (Shamshiry et al. 2015). Source separation is also fundamental for proper transportation and final disposal. Waste separation at home increases the potential for recycling, creating potential economic benefits for members of society (Gu et al. 2015). Waste separation also allows for composting and material recovery, which has a better environmental performance than a landfill as a disposal strategy (Erses Yay 2015).

A landfill is a less preferred option in waste management because it is riskier than recycling, reusing, composting, and waste segregation. Specifically, the generation of greenhouse emissions in landfills is known to be a significant contributor to global warming and climate change (Zuberi, Ali 2015). Methane alone accounts for about $50 \%$ of the biogas naturally produced in a landfill (Broun, Sattler 2016). Waste to energy technologies in landfills is an alternative to traditional landfills in that they reduce the odds of polluting ecosystems and 
decreasing climate warming by generating clean energy, mainly through controlling the generation of methane (Tozly et al. 2016).

Other serious environmental problems at landfill sites include leachate, which results from the liquids in waste, mainly organic wastes, getting in contact with other waste and polluting the soil or groundwater (Bhalla et al. 2013). Landfill leachate encompasses a wide variety of organic compounds like benzene, toluene, ethylbenzene, xylenes, chlorinated hydrocarbons, polycyclic aromatic hydrocarbons, and organochlorine pesticides that could be carcinogenic (Clarke et al. 2015). Toxic substances like lead and cadmium can also be present in streams surrounding landfills (Melnyk et al. 2014). Containment and attenuation strategies are often used to avoid damage to the environment from leachate (Regadío et al. 2015).

In a real-life decision-making process, most of the time, decision-makers adopt waste management practices based on the specific circumstances of their locale, so that it is likely that particular components of the waste management hierarchy are adopted. Likewise, the factors that may influence the adoption of particular waste management practices are those linked to individuals' culture, consumption, and living habits (Han et al. 2017).

There are also considerable differences in waste management practices between developed and developing countries and between urban and rural areas. Darban and Hajillo (2017) note that in rural zones, the most relevant factors that influence waste generation are: income, assets, age, and personal attitudes. The educational level of rural residents is another important factor where those with higher levels of education are more likely to adopt waste management practices (Wang et al. 2018).

In rural regions of developing countries, the lack of proper waste management practices increases the risk of harming health, biodiversity, and ecosystems, not to mention the economic loss related to not recycling or producing energy out of the waste (Mihai, Ingrao 2016). However, Boateng et al. (2016) notes that urban communities present worse waste management practices in streets and dumping sites than rural communities.

This paper is an exploratory study of a waste stream analysis. Using the waste management hierarchy as a guide, the purpose of this exploratory study is to identify 
opportunities to reduce environmental and health risks within a household waste stream of a small rural population in Northwestern Mexico.

\section{Research methods}

The study consisted of three phases. Firstly, a one-stage cluster sampling was conducted to characterize the household waste in this rural population. A cluster in this study was a block; there were 54 clusters in total, but only 40 with occupied houses. The clusters were selected by simple random sampling; the following equation was used:

Where:

$$
\mathrm{m}=\left\lceil A+\left.\sqrt{\left(A^{2}+\frac{n^{*}}{N}\right)}\right|^{2}[1]\right.
$$

$A=z_{\alpha} V_{N} / 2$

$z_{\alpha}=$ the $100 x$ th percentile of the standard normal distribution.

$V_{N}=\sigma_{N} / \bar{N}$

$\mathrm{M}=$ The number of clusters in the population.

$$
\sigma_{N}=\sqrt{\left[\sum_{i=1}^{M}\left(N_{i}-\bar{N}\right)^{2} / M\right]}[2]
$$

$N_{i}=$ The number of individuals in cluster $\mathrm{i} ; \mathrm{i}=1, \ldots, \mathrm{M}$.

$\overline{\mathrm{N}}=\sum_{i=1}^{M} N_{i} / M$ (the mean number of individuals per cluster).

$\mathrm{A}=$ estimation error of subject in the cluster

$\sigma_{N}=$ Standard deviation

$\mathrm{V}_{\mathrm{N}=}$ Standard deviation of $\mathrm{N}_{\mathrm{i}}$

Equation solving:

$$
\mathrm{A}=(1.96 * 4.1683) /(2 * 6.1)=0.6696 ; \text { at least } 100 \text { inhabitants }
$$

$\mathrm{M}=40 \quad m=\left[0.6696+\sqrt{\left(0.6696^{2}+\frac{100}{6.1}\right)}\right]^{2}$

$\mathrm{N}=244$

$\overline{\mathrm{N}}=6.1$

$\sigma_{N}=4.1683 \quad m=23$ clusters

Significance level (Alpha) $=0.025$

One social demographic characteristic of this location was that blocks were composed of very few houses, sometimes just one or two houses. For this reason, the research team decided to characterize 24 clusters representing 51 houses with 119 occupants. This is justified by the Law of the larger numbers who states that as 
the sample size grows, its mean gets closer to the average of the whole population. Figure 1, shown in red, represents the sampled clusters.

Figure 1. Cluster sampling on the rural area

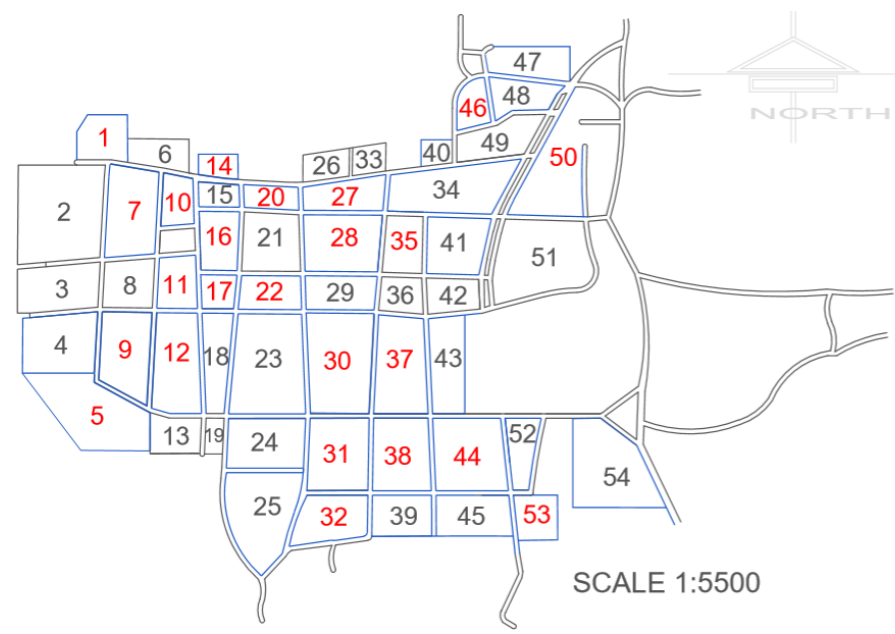

The characterization of the household waste took place in each of the 51 occupied houses. A representative person in each house was asked to deposit their garbage in a plastic bin during a 24-hour period during the month of January. Then, a member of the research team picked up, separated, and weighed each type of waste. Finally, the amount of organic and inorganic household waste was computed.

During the second phase of the study, a survey was conducted to examine the waste management practices of the residents in the sampled houses. Considering that 51 were the inhabited houses in the sampled clusters, a simple random sampling for finite populations was selected. The proportion, $\mathrm{p}=.25$, was based on responses from a pilot survey.

$$
n=\frac{n_{0}}{1+\frac{n_{0}}{N}} \quad \text { [Equation 3] }
$$


Equation solving:

$$
\begin{aligned}
& n_{0}=\frac{z^{2} p q}{e^{2}} \\
& n_{0}=\frac{2^{2} * 0.25 * 0.75}{0.1^{2}}=75
\end{aligned}
$$

$$
n=\frac{75}{1+\frac{75}{51}}=31
$$

Where:

$\mathrm{P}=$ estimated prevalence $=.25$

$\mathrm{Q}=1-\mathrm{p}=.75$

e Margin of error $=0.1$

$\mathrm{Z}$ statistic value $=2$ (rounded)

As thirty-one samples is a small sample size, the research team conducted the survey in each of the fifty-one occupied houses.

Finally, the third phase consisted of the characterization of the waste within the municipal landfill. For this purpose, a quadrant sampling method was conducted. The total area of the municipal landfill site was divided into black and white quadrants as shown in Figure 2. The white color is represented by tails while the black color is represented by heads. The color of the sampled quadrants was selected after 50 virtual coin flips for true randomness. The waste accumulated in the landfill for eight months.

\section{Figure 2. Quadrat sampling draw on the landfill area}

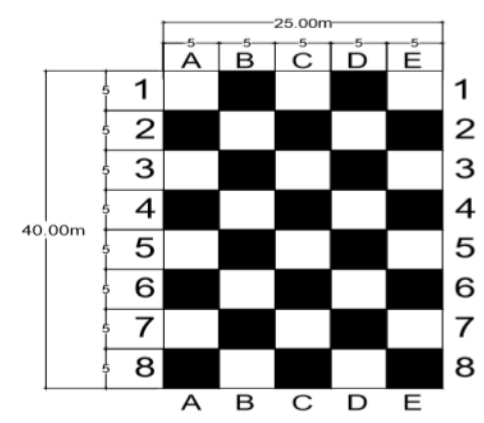




\section{Results}

In this section is presented the results for each of the phases where the characterization was performed. Firstly is given the results for the household waste, then the results for the survey, and finally, the characterization in the landfill site.

a) Household Waste Characterization

Organic household waste was more prominent than inorganic household waste. Table 1 shows $74 \%$ of the total household waste was organic while just twenty-six was inorganic. Table 2 shows that most of the organic waste came from leftover food, $79 \%$, followed by paper and paperboard, $14 \%$, and finally, foliage, accounting for $7 \%$. On the other hand, inorganic household waste was mostly characterized by plastic, with $80 \%$ of the total. Table 3 shows the breakdown of inorganic waste.

Table 1. Household waste classification

\begin{tabular}{|c|c|c|}
\hline $\begin{array}{c}\text { Household Waste } \\
\text { Classification }\end{array}$ & Percentage (\%) & Kilos per day period \\
\hline Organic & 64 & 29.34 \\
\hline Inorganic & 36 & 16.36 \\
\hline
\end{tabular}

Table 2. Household organic waste characterization

\begin{tabular}{|l|c|c|}
\hline $\begin{array}{c}\text { Organic Household Waste } \\
\text { Classification }\end{array}$ & Percentage (\%) & Kilos per day \\
\hline Leftover Food & 92 & 26.9 \\
\hline Foliage & 8 & 2.4 \\
\hline
\end{tabular}

Table 3. Household inorganic waste characterization

\begin{tabular}{|l|c|c|}
\hline $\begin{array}{c}\text { Inorganic Household Waste } \\
\text { Classification }\end{array}$ & Percentage (\%) & Kilos per day \\
\hline Paper and Cardboard & 28.5 & 4.66 \\
\hline Plastic & 57.1 & 9.35 \\
\hline Metals & 9.2 & 1.51 \\
\hline Glass & 4.5 & 0.73 \\
\hline Others & 0.8 & 0.13 \\
\hline
\end{tabular}




\section{b) Survey}

In total, $69 \%$ of the houses were occupied by one to three persons, $18 \%$ by four or five persons, and $14 \%$ by more than five. A majority of $88 \%$ of household waste was gathered in trash bins, $10 \%$ in plastic bags, and $2 \%$ use both garbage bins and plastic bags. All houses (100\%) had a free service waste recollection hauler offered by the municipality. In $96 \%$ of the homes, the service is provided once per week and in $4 \%$ of the houses, twice per week.

The primary inorganic waste material in houses was plastic, $53 \%$, followed by paper, $12 \%$, and glass with, $6 \%$. The mixture of several materials added up to $29 \%$. Ninety-four percent of the participants claimed to know that the landfill was the final destination of their household waste. Only $14 \%$ of the respondents claimed to segregate organic and inorganic waste. The primary purpose of the segregation is for compost elaboration. Ninety-four percent of the participants claimed to know about the recycling of household waste. A majority of $88 \%$ of the respondents were willing to participate in a recycling or reuse program, if a program is implemented by their municipality. Eighty-two percent of the respondents claimed they were aware of some health problems related to deficient waste management practices in houses. Only $34 \%$ thought that deficient waste management practices could lead to a combination of health disorders like dermatitis, diarrhea, and respiratory illness. Fifty-seven percent of the respondents have already experienced at least one of these disorders.

\section{c) Municipal Landfill Site and Disposal Waste Characterization}

The municipal landfill is an open dumping site that was opened eight months before the waste characterization was conducted. The area of the landfill is 1,000 square meters, 40 meters in length and 25 meters in width. The municipality waste hauler picks garbage up from houses once per week and the trash is deposited at the site, with no practices of waste management. There is no restriction to get into the landfill; any person can dump any kind of waste into the property. During the waste characterization, cows and donkeys were present, as well as pets, that were entering the site looking for food. 
Table 4 and Table 5 shows the percentages of organic and inorganic waste weighed at the landfill. Some organic waste could not be weighed because of its stage of decomposition. Foliage was the organic material that weighed the most, followed by wood and paper or paperboard. Used tires were the inorganic material that weighed the most, followed by plastic and fabrics.

Table 4. Organic waste characterization in the landfill

\begin{tabular}{|l|c|c|}
\hline \multicolumn{1}{|c|}{$\begin{array}{c}\text { Organic Waste } \\
\text { Classification }\end{array}$} & Percentage (\%) & Kilos in eight months \\
\hline Foliage & 79 & 40.8 \\
\hline Paper and Paperboard & 7 & 3.71 \\
\hline Wood & 14 & 7.32 \\
\hline
\end{tabular}

Table 5. Inorganic waste characterization in the landfill

\begin{tabular}{|l|c|c|}
\hline \multicolumn{1}{|c|}{$\begin{array}{c}\text { Inorganic waste } \\
\text { Classification }\end{array}$} & Percentage (\%) & Kilos in eight months \\
\hline Plastic & 14 & 11.33 \\
\hline Metals & 9 & 7.22 \\
\hline Glass & 9 & 7.27 \\
\hline Tires & 58 & 48.10 \\
\hline Fabrics & 12 & 9.63 \\
\hline
\end{tabular}

\section{Concluding remarks}

According to the inverted pyramid of non-hazardous materials management, source reduction practices are preferable over other methods. Source reduction practices relate to any initiative that could be conducted at homes by the occupants. The findings of this study highlight the willingness of the residents to participate in a reduction or recycling program. This finding is important because source reduction practices rely more on community involvement rather than on technology. Therefore, one opportunity to reduce environmental and health risks within the household waste stream at this small rural population is educating and training town residents to separate waste at home. Climate change is another hot topic that must be 
included in educational/training efforts (Perkins et al. 2018). Universities and research centers might be ke allies to support small rural location while keeping the investment affordable (Velazquez et al. 2000).

Dhokhikah et al. (2015) states that environmental knowledge, information from mass media, education and training, the existence of a catalogue of environmental indicators, and the existence of a waste bank are five supporting factors in household solid waste reduction initiatives. It is unlikely that all factors could be incorporated into a novel program by municipalities, yet, it is possible to start by educating and training and then gradually incorporating more elements into a potential initiative.

After all, lack of awareness separation is one of the predominant barriers to enhance community involvement (Zeng et al. 2016). Unfortunately, this rural municipality has neither the necessary infrastructure nor a recycling facility to obtain economic benefits out of the household waste. There are opportunities to promote composting as the findings showed that organic waste was the predominant material in the household waste composition. This mirrors other Latin American countries like Ecuador (71,4\%), Peru (54,5\%) and Guatemala (63,3\%) (Sáez et al. 2014). Countries in Asia, like China (55,8) (Mian et al. 2017), Malaysia (45\%), Iran (72\%), and Thailand (43\%), and (Taghuipour et al. 2016). Similar waste characteristics are noted in Denmark (41\%), Spain $(56,2 \%)$, Sweden $(33 \%)$, and Turkey (67\%) (Edjabou et al. 2015).

As is noted in our waste stream analysis, the total amount of household waste was disposed of in this landfill where waste management practices are inadequate. According to Mihai (2017), this same situation in rural areas occurs due to the lack of formal waste collection services. Undoubtedly, this situation can potentially lead to the occurrence of diseases, have an impact on ecosystems, and contribute to climate change.

The riskier situation revealed by this waste stream analysis were observed at the landfill site. Preventing affectations to the health of the inhabitants surrounding the landfill area should be a priority for the municipality. Inhabitants close to the landfill may suffer health problems from air pollutants and odorants from uncontrolled emissions (Palmiotto et al. 2014). 
As was shown in Table 5, tires were found among the waste within the landfill site. However, used tires were not characterized in houses. Rodseth et al. (2020) reports that illegal and not- recorded dumping is a limitation to improve waste management services in developing countries. Illegal dumping or un-recorded dumping occurred in this landfill. In the case of a fire, the presence of tires might pose a significant risk to the residents living close to the landfill because residents would be exposed to polluting emissions like particulates, carbon monoxide, sulfur oxides, oxides of nitrogen, volatile organic compounds, benzene, and others that can cause acute and chronic health hazards and affectations for the environment (Nadal et al. 2016).

Leachate was another problem detected at the landfill site that can be prevented, at least in part, by reducing the amount of organic waste in the landfill site. Since there is no technology to control leachate at the landfill, it is essential to adopt proper waste management practices like composting and source separation to prevent leachate polluting soil and surrounding streams.

This waste stream analysis provided here suggests that the most feasible opportunities to decrease environmental and health risks within the household waste stream are at the beginning of the waste stream. Municipalities should enhance waste separation at the source, in the houses, and implement composting techniques among residents. In this regard, the results from this study can serve as a starting point to analyze and compare sustainable opportunities in other rural zones around the world.

\section{References}

Bhalla B., Saini M.S., Jha M.K. (2013), Effect of age and seasonal variations on leachate characteristics of municipal solid waste landfill, "International Journal of Research in Engineering and Technology", vol. 02 no. 08, pp. 223-232.

Broun R., Sattler M. (2016), A comparison of greenhouse gas emissions and potential electricity recovery from conventional and bioreactor landfills, "Journal of Cleaner Production", vol. 112 part 4, pp. 2664-2673.

Boateng S., Amoako P., Appiah D.O., Poka A.A., Garsonu E.K (2016), Comparative analysis of households solid waste management in rural and urban Ghana, "Journal of Environmental and Public Health”, vol. 2016, http://downloads.hindawi.com/journals/jeph/2016/5780258.pdf [06.09.2020]. 
Clarke B.O., Anumol T., Barlaz M., Snyder S.A. (2015), Investigating landfill leachate as a source of trace organic pollutants, "Chemosphere”, vol. 127, pp. 269-275.

Darban Astane A.R., Hajillo M. (2017), Factors affecting the rural domestic waste generation, "Global Journal of Environmental Science and Management", vol. 3 no. 4, pp. 417-426.

Dhokhikah Y., Trihadiningrum Y., Sunaryo S. (2015), Community participation in household solid waste reduction in Surabaya, Indonesia, "Resources, Conservation and Recycling", vol. 102, pp. 153162.

Environmental Protection Agency (2017), Waste Management Hierarchy [Figure], https://www.epa.gov/smm/sustainable-materials-management-non-hazardous-materials-and-wastemanagement-hierarchy [06.09.2020].

Edjabou M.E., Jensen M.B., Götze R., Pivnenko K., Petersen C., Scheutz C., Astrup T.F. (2015), Municipal solid waste composition. Sampling methodology, statistical analyses, and case study evaluation, "Waste Management", vol. 36, pp. 12-23.

Erses Yay A.S (2015), Application of life cycle assessment (LCA) for municipal solid waste management. A case study of Sakarya, "Journal of Cleaner Production", vol. 94, pp. 284-293.

Gu B., Wang H., Chen Z., Jian S., Zhu W., Liu M., Chen Y., Wu Y., He S., Cheng R., Yang J., Bi J. (2015), Characterization, quantification and management of household solid waste. A case study in China, "Resources, Conservation and Recycling", vol. 98, pp. 67-75.

Han Z., Liu Y., Zhong M., Shi G., Li Q., Zeng D., Zhang Y., Fei Y., Xie Y. (2017), Influencing factors of domestic waste characteristics in rural areas of developing countries, "Waste Management", vol. 72, pp. 45-54.

Melnyk A., Kuklińska K., Wolska L., Namieśnik J. (2014), Chemical pollution and toxicity of water samples from stream receiving leachate from controlled municipal solid waste (MSW) landfill, "Environmental Research", vol. 135, pp. 253-261.

Mian M.M., Zeng X., Nasry A.a.N.B., Sulala M.Z.F. (2017), Municipal solid waste management in China. A comparative analysis, "Journal of Material Cycles and Waste Management", vol. 19 no. 3, pp. $1127-1135$.

Mihai F.-C., Ingrao C. (2016), Assessment of biowaste losses through unsound waste management practices in rural areas and the role of home composting, "Journal of Cleaner Production", vol. 172, pp. 1631-1638.

Mihai F.C. (2017), Waste collection in rural communities. Challenges under EU regulations. A case study of Neamt County, Romania, "Journal of Material Cycles and Waste Management", vol. 20, pp. 1337-1347.

Munguia N., Zavala A., Marin A., Moure-Eraso R., Velazquez L. (2010), Identifying pollution prevention opportunities in the Mexican autorefinishing industry, "Management of Environmental Quality: An International Journal", vol. 21 no. 3, pp. 324-335. 
Nadal M., Rovina J., Díaz-Ferrero J., Shuhmacher M., Domingo J.L. (2016), Human exposure to environmental pollutants after a tire landfill fire in Spain. Health risks, "Environmental International", vol. 97, pp. 37-44.

Palmiotto, M., Fattore, E., Paiano, V., Celeste, G., Colombo, A., Davoli, E. (2014), Influence of a municipal solid waste landfill in the surrounding environment: Toxicological risk and odor nuisance effects, "Environmental International", vol. 68, pp. 16-24.

Perkins K., Munguia N., Moure-Eraso R., Delakowitz B., Giannetti B., Gengyuan L., Nurunnabi M., Will M., Velazquez L. (2018), International perspectives on the pedagogy of climate change, "Journal of Cleaner Production", vol. 200, pp. 1043-1052.

Regadío M., Ruiz A.I., Rodríguez-Rastrero M. (2015), Containment and attenuating layers. An affordable strategy that preserves soil and water from landfill pollution, "Waste Management", vol. 46, pp. 408-419.

Rodseth C., Notten P., Von Blottnitz H. (2020). A revised approach for estimating informally disposed domestic waste in rural versus urban South Africa and implications for waste management, "South African Journal of Science", vol. 116 no. 1/2, file:///C:/Users/Anka/AppData/Local/Temp/5635Main\%20document-42273-1-10-20200128.pdf [06.09.2020].

Sáez A., Urdaneta G., Joheni A. (2014), Solid waste management in Latin America and the Caribbean, "Omnia", vol. 20 no. 3, pp. 121-135.

Soltani A., Hewage K., Reza B., Sadiq R. (2015), Multiple stakeholders in multi-criteria decisionmaking in the context of Municipal Solid Waste Management. A review, "Waste Management", vol. 35 , pp. 318-128.

Shamshiry E., Mokhtar M.B., Abdulai A.M., Komoo I. (2015), Using the analytic hierarchy process to enhance sustainable solid waste management. Case study of Langkawi Island, Malaysia, "Environmental Quality Management", vol. 24 no. 4, pp. 51-64.

Taghipour H., Amjad Z., Aslani H., Feridoum A., Reza D. (2016), Characterizing and quantifying solid waste of rural communities, "Journal of Material Cycles and Waste Management", no. 4, pp. 790-797.

Tozlu A., Özahi E., Abuşoğlu A. (2016), Waste to energy technologies for municipal solid waste management in Gaziantep, "Renewable and Sustainable Reviews", vol. 54, pp. 809-815.

Velazquez L., Munguia N., Platt A. (2000), Fostering P2 practices in northwest Mexico through interuniversity collaboration, "Journal of Cleaner Production", vol. 8 no. 5, pp. 433-437.

Wang F., Cheng Z., Reisner A., Liu Y. (2018), Compliance with household solid waste management in rural villages in developing countries, "Journal of Cleaner Production", vol. 202, pp. 293-298.

Zeng C., Niu D., Li H., Zhou T., Zhao Y. (2016), Public perceptions and economic values of sourceseparated collection of rural solid waste. A pilot study in China, "Resources, Conservation and Recycling”, vol. 107, pp. 166-173.

Zuberi M.J.S., Ali S.F (2015), Greenhouse effect reduction by recovering energy from waste landfills in Pakistan, "Renewable and Sustainable Energy Reviews", vol. 44, pp. 117-131. 